\title{
Strengthening nurses in prenatal care through reflection-action
}

How to cite this article: Benedet DCF, Wall ML, Lacerda MR, Machado AVMB, Borges R, Zômpero JFJ. Strengthening nurses in prenatal care through reflection-action. Rev Gaúcha Enferm. 2021:42:e20200187. doi: https://doi.org/10.1590/19831447.2021.20200187 anniversidade Federal do Paraná (UFPR), Departamento de Enfermagem, Programa de PósGraduação em Enfermagem. Curitiba, Paraná, Brasil. - Fundação de Apoio da Universidade Federal do Paraná (FUNPAR). Curitiba, Paraná, Brasil.

Centro Hospitalar de Reabilitaçăo Ana Carolina Moura Xavier Curitiba, Paraná, Brasi.

Prefeitura Municipal de Pinhais, Departamento de Atenção Primária à Saúde. Pinhais, Paraná, Brasil.

\section{ABSTRACT}

Objective: To describe the reflection-action process for the development of nurses' competence in prenatal care

Method: Action research with 30 nurses from primary health care in a municipality in the south of the country, through workshops held between June and August 2019, analyzed according to Creswell.

Results: Nurses identify nursing consultation as a differential in prenatal care; point out the ignorance of work processes as an obstacle to the protagonism in prenatal care; and they highlight the registration of activities and the dissemination of the nurse's role with the team and the population as aspects that strengthen and value the profession.

Conclusion: The workshops enabled reflection to identify and overcome obstacles to the development of a competent practice, by strengthening nurses regarding the work process itself to discuss and implement changes in order to improve and enhance the care provided.

Keywords: Education, nursing. Professional training. Empowerment. Primary care nursing. Prenatal care. Qualitative research.

\section{RESUMO}

Objetivo: Descrever o processo de reflexão-ação para o desenvolvimento de competência de enfermeiras no cuidado pré-natal.

Método: Pesquisa-ação com 30 enfermeiras da atenção primária à saúde de um município da região sul do país, mediante oficinas realizadas entre junho e agosto de 2019, analisadas segundo (reswell.

Resultados: As enfermeiras identificam a consulta de enfermagem como um diferencial no cuidado pré-natal; apontam 0 desconhecimento dos processos de trabalho como óbice ao protagonismo no cuidado pré-natal; e destacam o registro das atividades e divulgação do papel da enfermeira junto a equipe e a população como aspectos que fortalecem e valorizam a profissão. Conclusão: As oficinas possibilitaram a reflexão para identificação e superação dos óbices ao desenvolvimento de uma prática com competência, mediante o fortalecimento das enfermeiras quanto ao próprio processo de trabalho para discutirem e implementarem transformações a fim de aprimorar e valorizar o cuidado prestado.

Palavras-chave: Educação em enfermagem. Capacitação profissional. Empoderamento. Enfermagem de atenção primária. Cuidado pré-natal. Pesquisa qualitativa.

\section{RESUMEN}

Objetivo: Describir el proceso de reflexión-acción para el desarrollo de competencia de enfermeras en la atención prenatal. Método: Investigación-acción con 30 enfermeras de atención primaria de salud en un municipio del sur del país, a través de talleres entre junio y agosto de 2019, analizados según Creswell.

Resultados: Las enfermeras identifican la consulta de enfermería como un diferencial en la atención prenatal; señalan la ignorancia de los procesos de trabajo como obstáculo al protagonismo; y destacan el registro de actividades y la difusión del papel de la enfermera junto al equipo y la población como fortalecedores y valoradores a la profesión.

Conclusión: Los talleres permitieron reflexinar para identificar y superar los obstáculos al desarrollo de una práctica competente, al fortalecer las enfermeras con respecto a su proceso de trabajo para discutir e implementar cambios con el fin de mejorar y valorar la atención brindada.

Palabras clave: Educación en enfermería. Capacitación profesional. Empoderamiento. Enfermería de atención primaria. Atención prenatal. Investigación cualitativa. 


\section{INTRODUCTION}

In recent decades, there has been an increase in prenatal care activities based on the justification that greater contact with health workers during pregnancy helps reduce maternal-infant morbidity and mortality rates ${ }^{(1)}$.

However, rates of preventable maternal mortality remain high, especially in developing countries such as Brazil. Therefore, signatory countries of the Sustainable Development Goals (SDGs) are redefining new targets to improve maternal health and reduce maternal mortality worldwide to less than 70 cases per 100,000 live births by the year 2030(1).

To achieve the SDGs and considering the greater focus on the role of health workers, especially nurses, who represent the largest health care workforce in Brazil, it is necessary to prepare these workers for the provision of care with competence. From this perspective, the Triple Impact report stresses that nursing must be developed to improve health care, promote gender equality, since most of the category is made up of women, and strengthen the economy ${ }^{(2)}$.

The WHO report on the situation of nursing worldwide states that nursing is essential for the fulfillment of SDGs, not only in terms of specific health conditions but with regard to the role of nursing in education, gender equity, and economic development ${ }^{(3)}$.

Intending to strengthen the critical role of nurses in health care and allow them to practice with full potential and contribute to universal access to health care, the World Health Organization and the International Nursing Council established the global Nursing Now campaign, with a planned duration of three years, from 2018 to $2020^{(2-4)}$.

In the specificity of prenatal care and given the $4.5 \%$ to $66.1 \%$ variability in the rates of inadequate prenatal care in Brazil ${ }^{(5)}$, it is necessary to pay attention to the effectiveness of the care provided. Moreover, the provision of evidence-based care that meets the individual needs of pregnant women and focuses on the continuity of care ${ }^{(6)}$ is essential for a positive experience during pregnancy ${ }^{(7)}$.

To identify the needs of pregnant women and develop care that influences them, the health workers involved in care must have competence ${ }^{(7)}$, which corresponds to the way in which the subject rationally and reflexively mobilizes and employs the internal resources available in terms of knowledge and skills to effectively solve a given problem or situation ${ }^{(8)}$.

In this regard, aligned with the global movement to raise the profile of nursing and aiming to strengthen and value the profession ${ }^{(2,4)}$, supported by the document of the
International Confederation of Midwives (ICM) updated with regard to competencies in obstetric care ${ }^{(9)}$, the following research question was raised, "How to promote reflection-action for the development of competence in prenatal care?". The present study aimed to describe the reflection-action process for the development of nurses' competence in prenatal care.

\section{$\square$ METHOD}

This is a qualitative study based on the research action method. The capacity for this method to expose complex problems is characterized by the narrow composition between objectives of knowledge - related to the research - and practice - related to an action - through the participation and cooperation of researchers and participants who represent the investigated condition, with the aim of increasing the knowledge or "level of consciousness" of all the parties involved, not limited to mere action ${ }^{(10)}$.

This method is divided into 12 flexible and concomitant stages, starting with the situational diagnosis of the phenomenon investigated in the exploratory phase, followed by the research theme; problem placement; place of theory; hypotheses; seminar; field of observation, sampling, and qualitative representativeness; data collection; learning; formal/informal knowledge; and action plan, ending with the external divulging of results, in a circularity between research and action ${ }^{(10)}$.

The seminar phase corresponds to the moment when all information is centralized and enables its interpretation by the participants together with the theoretical mediation of the researcher who bases and helps the reflection of those involved in the process ${ }^{(10)}$. This stage was structured into workshops ${ }^{(11)}$.

The sequence of study development followed the protocol consolidated criteria for reporting qualitative studies $\left(\right.$ COREQ) ${ }^{(12)}$.

The research participants were primary care nurses of a municipality in the metropolitan region of a capital city in southern Brazil, with 11 family health units ("USF") and a women's and children's health ("USMC") coordinated by at least one nurse.

Given the conception of action research, in which all the subjects involved in the process are considered participants, intentional sampling was used ${ }^{(10)}$ and the participation of all nurses who provided prenatal care was considered important. Nurses who had been working in the municipality were included in the study and nurses on vacation or leave during data collection were excluded, totaling 30 male and 
female nurses from the USF and USM, two of whom at the time of the workshops occupied administrative positions at the department of primary care.

The workshops were initially conducted in three moments. In the first meeting, the awareness of the participants was raised regarding the care performed. Because the problem in action research is defined with the participants to ensure it makes sense to them and triggers the desired transformations $s^{(10)}$, the generating themes raised at the end of each workshop supported the following workshops regarding the need for discussions and theory-practice approaches.

The workshops were held in June, July, and August 2019 and conducted by the principal researcher with the support of undergraduate nursing students from the proposing Institution who also collaborated in other stages of the study. Each workshop lasted 3 hours and 30 minutes and was conducted in two shifts so the nurses could attend during their shift without hindering their work.

Each meeting was audio and video recorded for subsequent transcription, resulting in 943 minutes of recordings. Field journals for the analysis and interpretation of the object studied ${ }^{(13)}$ were also provided after each workshop by the principal researcher to record a description of the workshop and any thoughts triggered and methodological factors that should be improved for greater depth and quality of information. Moreover, a collaborating undergraduate student made notes on any relevant factors.

Due to a partnership with the local board of the department of primary care, the workshops were conducted in the auditorium of the municipal health secretariat on days and times agreed between management, nurses of the health units, and the researcher.

At the end of each workshop, each meeting was evaluated using three different colored sheets of paper on which the participants wrote about what they had brought, what they contributed, and what they took from the workshop. As a form of gratitude and to promote the continuity of the nurses'reflection on the topics discussed, gifts related to the topic addressed with motivational phrases were distributed.

Materials from the workshops were analyzed according to the six steps recommended by Creswell. First, the data were organized the prepared for analysis, followed by reading and detailing for coding; then, the data were described for analysis representation and, finally, the findings were interpreted ${ }^{(14)}$.

Because the generating themes of each workshop were the guiding principles of the following meeting, a previous analysis took place concurrently with data collection. Final coding resulted in three thematic categories, represented by the statements of participants and attributed the letter "E" followed by the number corresponding to the order of collection to ensure secrecy and anonymity.

This study was approved by the Research Ethics Committee of the proposing higher education institution under opinion No. 2.616.148, registered in Plataforma Brasil under CAAE 83070218.0.0000.0102, and authorized by the local health department of the participating municipality. The ethical precepts of research with human beings were observed and informed consent was obtained from all participants.

\section{RESULTS}

The mean age of the participants was 46.4 years, ranging from 30 to 58 years. They were predominantly female, married, or with a stable partner and with children. As for education, most had private university studies, ranging from 8 to 30 years and an average of 17 years since graduation. Mean time working in prenatal care was 9 years, ranging from 6 months to 27 years.

Specialization in areas related to primary care was prevalent, with four participants specializing in obstetrics and one participant with an academic master's degree. Continuing education in prenatal care mainly consists of courses and training offered by the municipality.

The themes that emerged from data coding were nursing consultation as an advantage in prenatal care, obstacles to protagonism in prenatal care, and factors that strengthen and value nurses in prenatal care.

\section{Nursing consultation as an advantage in prenatal care}

According to the nurses, the advantages of nursing consultations in prenatal care are the creation and strengthening of a bond with the pregnant women and their families, the provision of care guidelines and education, and listening to the needs of the pregnant women and answering their questions to reassure them and convey security. They highlight the importance of the clinical factors but stress that nursing care covers other factors.

Assisting pregnant women as a whole (health, housing, diet, work, etc...). Scheduling regular consultations that cover all anamnesis, physical examination, prescribing vitamins, requesting tests, providing guidelines on all signs and symptoms. [...] the needs are not only physical, it depends. A pregnant woman needs some sense of security, 
know what is happening to her, what she is feeling. [...] If a health worker merely says, "Oh, that's part of the pregnancy, it's normal', she will not understand. (E07)

It is about offering a unique outlook to patients, aimed at understanding their desires and transmitting knowledge and security. (E10)

It is about being receptive, it is about knowing how to evaluate to make the right decisions. Nursing care is about being available to each other, it can be through a procedure or a word, or both. (E12)

The data reveal that the nurses understanding the need for competence in prenatal care if they hope to identify and respond to the needs of pregnant women during consultations based on their individuality and comprehensiveness. However, as explained in the following theme, they have difficulties implementing the described care.

\section{Obstacles to protagonism in prenatal care}

The participants had difficulty in defining factors that are exclusive to the profession. This inability, associated with the high demand for services, causes a "distortion" of nursing care and reveals some insecurity regarding their effective role in the team. These factors, combined with the centrality of nurses as coordinators of the team, sometimes leads to an accumulation of activities:

It is difficult even for us [to know what the work of nurses ultimately involves]. (E01)

We do other people's work and do not do our work. (E22) We need to stop taking on that burden and responsibility. Because we are doing the work of reception, [...] screening, everything. (E23)

The nurses mainly stressed the need for a greater number of health workers due to the high demand, worsened by the lack of team-sense among workers, which causes anxiety and guilt for prolonging consultations, as well as lack of focus and attention during care, resulting in consultations of lower quality.

[...] When it is in my interest, I go after it and do it. Now when it does not benefit me, when it is not specifically beneficial [...] you don't have that team-sense when it doesn't benefit you [...]. (E14)

[...] we want to sit down and do the nursing consultation, but it ends up being impaired and we sometimes end up giving patients a low-quality result [...] / felt guilty about staying an hour in the room, it gives other the impression that I am not doing anything. (E24)

The difficulty / see [...] is to be fully present for that patient, because you are interrupted, because you have to check things at the unit and see the patient, then you lose your train of thought, and you have to ask the patient again, which is annoying, "Where were we?". (E26)

This perspective distorts the real purpose of care provided in nursing consultations and suggests exhaustive work that sometimes becomes invisible to the eyes of management, the team, the users of the service, and often, the health workers who perform it, as they are not aware of their role and practice due to daily demands of their daily routines.

The lack of clarity as to the organization of work and recognition of the strictly nursing-related tasks generates insecurity and weakens the category in relation to other professional classes in health care. There is a need to organize the work processes and service activities, as shown below:

Even if you stand your ground, it is still very cultural in Brazil, this nursing thing [...] certain health workers say things like, "I will be respected because I have this profession"; this is already certain. (E12)

At all times, professional nurses have to show what their function is, why they are there [...] we had to sit down with the medical specialists because they were questioning why the nurse was consulting [subsequent prenatal] appointments]. (E13)

Another aspect that hinders the recognition of consultations performed by nurses is the reinforcement of the medical-centered model and the non-appreciation of the work they perform, as shown below:

Something that we do is consult in the corridors, when people stop us and ask us to solve their problem, that is terrible! Because it deprofessionalizes what we do. (E23)

Sometimes it's the statements they use, we use the words, and the staff says, "Oh, I will get the nurse to talk to you, okay?". He is in the system and such, but he understands that he is "talking" to the nurse. (E12)

The excerpts regarding the obstacles to competence in care show their awareness of the work process, which can support the creation of strategies to overcome difficulties and strengthen their role as professionals. 


\section{Factors that strengthen and value nurses in prenatal care}

From the reflections and provocations carried out during the workshops, the nurses implemented strategies to improve the care provided to pregnant women during prenatal consultations, such as performing and recording the physical examination and incorporating a script to guide annotations in the electronic medical record, mentioned by the nurses as a way of gaining visibility.

[what I didn't do and I started doing differently] was the notebook, the part of the physical exam, which I didn't do, I only filled in weight, height and such, only the basics, pressure, that was in it. I wouldn't do it, ask, look, check....(E02)

I had a script, so I added some questions [...] so the next health worker who looks at the medical record already has access to that. (E08)

I made a model of SOAP [...] and I passed it onto some colleagues, with all the data processed to date. It makes things easier because it turns into something standard. And I already applied it, it was good! (E1 1)

We will only gain visibility if we record what we do. (E15)

Another aspect mentioned by the participants was reflection on the professional practice itself and the delegation of procedures that are not exclusive to nurses, to enable greater focus on the nursing consultation.

This self-criticism that we have to do, we are not used to doing it! We do the work mechanically, we do not reflect on it, what I did is right and that's it [...] was / 100\% right? Was it the correct technique? Did I give the patient the attention she needed? (E14)

[...] we need to delegate, many things are done in the associated consultation, so we can really do a nursing consultation. I got the quick tests from the pregnant woman's consultation. [...] (E23)

To be with that patient, give that patient my full attention and attend to one thing at a time. (E15)

During the discussions, the nurses were given strategies that could be implemented both regarding organization with the team to optimize and value the work and activities with the support of management. One such strategy with the creation of videos for viewing in the waiting rooms to raise awareness of the role of nurses and of other members of the health team. Another strategy was the widespread promotion of management of training and legal achievements that further support the work of nurses.

You had to focus on organizing the work process, you know? Because if you do not do things when they are happening, it cannot be planned. You can't mix things up, everyone has their role! [...] you have to guarantee health workers can work freely within their responsibilities! (E12) Television, we can put some guidelines on the panel. Put up there, nursing consultation, what is the nursing consultation. (E23)

This visibility, this empowerment has been given, now I think it has to be publicized. [...] make it very clear what we can and can't do. (E12)

The nurses reinforced the need to divulge their job descriptions because culturally, in Brazil, the role of nurses is not fully understood and health care is centered on the figure of the physician.

In the dynamics of the final evaluation carried out at each meeting, the most frequently mentioned words regarding what they had brought to the workshop were, "expectations, doubts, anxiety, curiosity"; what they had left, "experiences, doubts, anxieties and insecurities"; and what they took with them, "knowledge, reflections, motivation, will".

In line with these considerations regarding participation in the workshops, it was observed that nurses value training as a strategy of lifelong education and stress the need for a greater relationship between theory and practice, as well as the inclusion of discussions as important approaches to the development of competence. The statements revealed the need for reflection in order to identify the theme based on the demand of health workers in a non-vertical way.

Today, there is quite a lot regarding health care education but it is always based on the assumption that you already know "such and such", so we only move from there onwards, but sometimes you have to go back to the basics. To provide practice activities. (E12)

[...] When you mentioned the workshop, I thought, "Oh, so someone from the academic world will come along and tell us that we are carrying all the burden", but it was quite different, at no time did impose anything, it was very nice, it was very good to reflect on it (E08)

There is an impasse between the training and creating the conditions to effectively make changes in the professional practice, and the workshops allowed them to share the 
hindrances experienced and exchange knowledge among the professionals.

\section{DISCUSSION}

Nursing as a social practice incorporates a holistic philosophy and education, centered on people, thus enabling continuity of care and the capacity to be present when other professionals are not ${ }^{(5)}$. The primary care model led by nurses has proved effective and shown similar or even better health-related outcomes and greater user satisfaction than other care models ${ }^{(3)}$.

This model has been satisfactory for the provision of good quality prenatal care when health workers receive training, monitoring, and evaluations of the practice performed, associated with a quality service ${ }^{(15)}$. To accomplish quality health care, the work of qualified and competent professionals must be based on three domains: clinical practices; relevant and timely information; and psychosocial and emotional support ${ }^{(7)}$.

Nurses are one of the health professionals who are identified as fundamental for the provision of essential care and they conduct important work to strengthen the health system $^{(1)}$. They play a relevant role in the transformation of the medicalized model and the recovery of care and act mainly through nursing consultations with health guidelines for individuals and families ${ }^{(16)}$.

Although the participants of the present study expressed this perception of their own practice, they identify obstacles related to improving the working conditions of nursing professionals so that they can develop care competently, and the need to strengthen education to raise the level of appropriation of the work process itself with the team and assisted population.

The culture of medicalization strongly ingrained in the population and among some members of the health care team, bureaucracy, and verticalized management determinations conform to the reproduction of this model to the extent that they do not benefit assistance, qualified listening, and humanized care in the health practice ${ }^{(16)}$, all of which were pointed out as potentialities for prenatal care with competence. In contrast, the lack of knowledge and skill of the nurses, high turnover, which makes it difficult to form a bond with users and coordinate work with the team, evaluations of production based on quantitative goals, and an excess of bureaucratic work hinder the provision of prenatal care with competence ${ }^{(17)}$.

As expressed by the nurses of the present study regarding the purpose of prenatal care and the factors that characterize the advantages of nursing consultation, pregnant women perceive prenatal care as positive when it includes humanized assistance based on their subjectivity and the provision of information that reassures them ${ }^{(18)}$.

Competence can be understood as a product of a learning process, but also as a foundation of human action ${ }^{(9)}$. In the specificity of obstetric care, the general competencies that apply to the various aspects of practice, including the responsibilities of health workers and their relationship with women and the team, should be considered the basis for strengthening the care provided, especially with regard to competence for actions that favor the autonomy of women and health workers, ethics, and the promotion of self-development in the nursing profession ${ }^{(10)}$.

Thus, the subject must develop the ability to learn and absorb the maximum information from each situation, since it takes time to acquire knowledge and train its use ${ }^{(9)}$. In this regard, there is a continuous need for quality education and competent health workers ${ }^{(1)}$, since the development of competence is influenced by a triad of factors, in which the professional's interest in learning converge; a work environment that encourages learning; and an available training system ${ }^{(9)}$.

Moreover, permanent education, acceptance of user feedback, and greater integration between care services, teaching, and class associations can support the development of competence in prenatal care ${ }^{(17)}$.

Permanent health education strategies that help maintain quality and update the professional practice for competent care are also needed. Similarly, management must incorporate education into its planning and seek to form partnerships to ensure permanent education projects, beyond the compartmentalized, discontinued, and technicist approach, that are linked to the needs of health workers and users, thus enabling the revitalization and transformation of the care and management work processes ${ }^{(19)}$.

Support and dialogue between governments and regulatory institutions of the profession are necessary to implement effective changes, facilitate investment decision-making in nursing, strengthen primary care, achieve universal health coverage, and move towards the SDGs $s^{(1,3)}$.

The local involvement and coordination of educational institutions and health services are needed to strengthen nursing through the development of competence and enable nurses as the protagonists of care; moreover, investments in the workforce and valorization of nursing professionals, improved training, and, above all, collective and participative work within and among organizations are required to achieve the desired advances for the profession $(5,17)$.

Nurses should be able to work to their full potential, but they cannot achieve this goal singlehandedly. Health management and political leaders must be involved in 
strengthening nurses as protagonists and transforming existing limiting perceptions of the profession ${ }^{(5)}$.

In order to achieve professional appreciation and visibility, nurses must effectively appropriate their care skills and have the capacity for political articulation, so they can manage practice situations and the health demands of society ${ }^{(20)}$. As pointed out by the nurses of the present study, the work carried out must be divulged in all channels that position nursing care as a social practice ${ }^{(20)}$.

This study had some limitations, such as the reality circumscribed to a municipality, making generalizations difficult. However, the findings can support reflections of managers regarding the implementation of permanent health education strategies that promote professional self-reflection as the practice of care in order to define actions from the reality of health services and ensure the desired transformations make sense to the workers and can thus reflect on improved care to users.

In this regard, the present study contributes to the valorization and strengthening of nursing and bridges the gap between teaching and health services to ensure the protagonism of this profession.

\section{FINAL CONSIDERATIONS}

The provocations and reflections during the workshops encouraged the nurses to identify possibilities for professional strengthening, recover the potentiality of their professional practice, and envision and implement alternatives to reorganize their work process through achievable solutions, as well as reassess their behaviors.

The competence of nurses in prenatal care is understood as the ability to monitor consultations with in-depth knowledge about pregnancy, childbirth and the puerperium, and care centered on the needs of women.

Nurses who provide prenatal care with competence contribute to the valorization and strengthening of nursing as a profession and support the transformation of the health care model, which is reflected in lower maternal and child morbidity and mortality rates and in the effective participation of women during the gestational process.

Health service management and professional class associations play a critical role in promoting actions to overcome the obstacles that hinder the valorization of nurses as a protagonist in health care and encourage nursing education, research, and training aligned with the precepts of the Nursing Now campaign, thus further promoting public and governmental awareness about the importance of the profession.

\section{REFERENCES}

1. World Health Organization (CH). Global strategic directions for strengthening nursing and midwifery 2016-2020. Geneva: WH0; 2016 [cited 2020 May 12]. Available from: https://www.who.int/hrh/nursing_midwifery/global-strategicmidwifery2016-2020.pdf

2. Crisp N, Iro E. Nursing now campaign: raising the status of nurses. Lancet. 2018;391(10124):920-1. doi: https://doi.org/10.1016/S0140-6736(18)30494-X

3. World Health Organization (CH). State of the world's nursing 2020: investing in education, jobs and leadership. Geneva:WH0; 2020 [cited May 12]. Available from: https://apps.who.int/iris/bitstream/handle/10665/331677/9789240003279-eng. pdf? sequence $=1 \&$ is Allowed $=y$

4. All-Party Parliamentary Group on Global Health (UK). Triple Impact: how developing nursing will improve health, promote gender equality and support economic growth. London: APPG; 2016 [cited 2020 Apr 30]. Available from: https://www. who.int/hrh/com-heeg/digital-APPG_triple-impact.pdf

5. Nunes JT, Gomes KRO, Rodrigues MTP, Mascarenhas MDM. Quality of prenatal care in Brazil: review of published papers from 2005 to 2015. Cad Saude Colet. 2016 Jun 20;24(2):252-61. doi: https://doi.org/10.1590/1414-462X201600020171

6. Kennedy HP, Cheyney M, Dahlen HG, Downe S, Foureur MJ, Homer KSE, et al. Asking different questions: a call to action for research to improve the quality of care for every woman, every child. Birth. 2018;45(3):222-31. doi: https://doi. org/10.1111/birt.12361

7. Downe S, Finlayson K, Tunçalp Ö, Gülmezoglu AM. What matters to women: a systematic scoping review to identify the processes and outcomes of antenatal care provision that are important to healthy pregnant women. BJOG. 2016;123(4):52939. doi: https://doi.org/10.1111/1471-0528.13819

8. Perrenoud P. Desenvolver competências ou ensinar saberes? a escola que prepara para a vida. Porto Alegre: Penso; 2013.

9. International Confederation of Midwives (ICM). Essential Competencies for Midwifery Practice: 2018 update. Den Haag: ICM; 2019 [cited 2020 Apr 30]. Available from: https://www.internationalmidwives.org/assets/files/general-files/2019/02/ icm-competencies_english_final_jan-2019-update_final-web_v1.0.pdf

10. Thiollent M. Metodologia da pesquisa-ação. 18. ed. São Paulo: Cortez; 2011.

11. Afonso MLM, organizadora. Oficinas em dinâmica de grupo na área da saúde. São Paulo: Casa do Psicólogo; 2013.

12. Tong A, Sainsbury P, Craig J, Consolidated criteria for reporting qualitative research (COREQ): a 32-item checklist for interviews and focus groups. Int I Qual Health Care. 2007;19(6):349-57. doi: https://doi.org/10.1093/intqhc/mzm042

13. Tonin L, Lacerda MR, Favero L, Nascimento JD, Zagonel IPS. Diário de campo na pesquisa qualitativa de enfermagem: da teoria à prática. In: Lacerda MR, Ribeiro RP, Costenaro RGS, organizadoras. Metodologias da pesquisa para a enfermagem em saúde: da teoria à prática. Porto Alegre: Moriá, 2018. v.2, p. 373-98.

14. Creswell JW. Projeto de pesquisa: métodos qualitativo, quantitativo e misto. 3. ed. Porto Alegre: Artmed; 2010.

15. Pricilla RA, David KV, Siva R, VimalaTJ, Rahman SP, Angeline N. Quality of antenatal care provided by nurse midwives in an urban health centre with regard to low-risk antenatal mothers. Indian J Community Med. 2017;42(1):37-42. doi: https://doi. org/10.4103/0970-0218.199796

16. Azevedo AR, Duque KSD. [The caring versus the medicalization of health in the view of nurses from Primary Health Care]. Rev APS. 2016 [cited $2020 \mathrm{Apr}$ 24];19(3):403-11. Portuguese. Available from: https://periodicos.uff.br/index. php/aps/article/view/15638 
17. Benedet DCF, Wall ML, Lacerda MR, Thuler ACMC, Szpin CC, Piler AA. Nursing competence in prenatal care: potentialities, barriers and possibilities. Rev Enferm Cent-0este Min. 2019:9:e3470. doi: https://doi.org/10.19175/recom.v9i0.3544

18. Livramento DVP, Backes MTS, Damiani PR, Castillo LDR, Backes DS, Simão MAS. Perceptions of pregnant women about prenatal care in primary health care. Rev Gaucha Enferm. 2019;40:e20180211. doi: https://doi. org/10.1590/1983-1447.2019.20180211

\section{- Acknowledgements:}

We would like to thank the pro-rectory of research and graduate studies of the Federal University of Paraná, for approval in the Notice 04/2019 - Support for research activities, and the Coordination of Improvement of Higher Education Personnel for the Social Demand grant.

\section{- Author contributions:}

Conceptualization: Deisi C. Forlin Benedet, Marilene Loewen Wall, Maria Ribeiro Lacerda.

Data curator: Deisi Cristine Forlin Benedet, Marilene Loewen Wall.

Formal analysis: Deisi C. Forlin Benedet.

Acquisition of financing: Deisi C. Forlin Benedet, Marilene Loewen Wall, Maria Ribeiro Lacerda.

Conceptualization: Deisi C. Forlin Benedet, Rayssa

Borges, Jaqueline Fumes Juvenal Zômpero.

Methodology: Deisi C. Forlin Benedet, Marilene Loewen

Wall, Maria Ribeiro Lacerda.

Project administration: Marilene Loewen Wall.

Resources: Deisi Cristine Forlin Benedet.

Supervision: Marilene Loewen Wall, Maria Ribeiro

Lacerda.

Validation: Deisi C. Forlin Benedet, Marilene Loewen

Wall, Maria Ribeiro Lacerda.

Writing - original draft: Deisi Cristine Forlin Benedet.

Writing - review and editing: all authors.

\section{- Corresponding author:}

Deisi Cristine Forlin Benedet

Email: deisiforlin@ufpr.br
19. Silva LAA, Soder RM, Petry L, Oliveira IC. Permanent education in primary health care: perception of local health managers. Rev Gaucha Enferm. 2017 Mar;38(1):e58779. doi: https://doi.org/10.1590/1983-1447.2017.01.58779

20. Lacerda MR. Valuation and visibility of nursing [editorial]. Cogitare Enferm. 2018;23(2). doi: https://doi.org/10.5380/ce.v23i2.60363

\section{Associate editor:}

Jéssica Machado Teles

Editor-in-chief:

Approved: 11.17.2020
Maria da Graça Oliveira Crossetti 